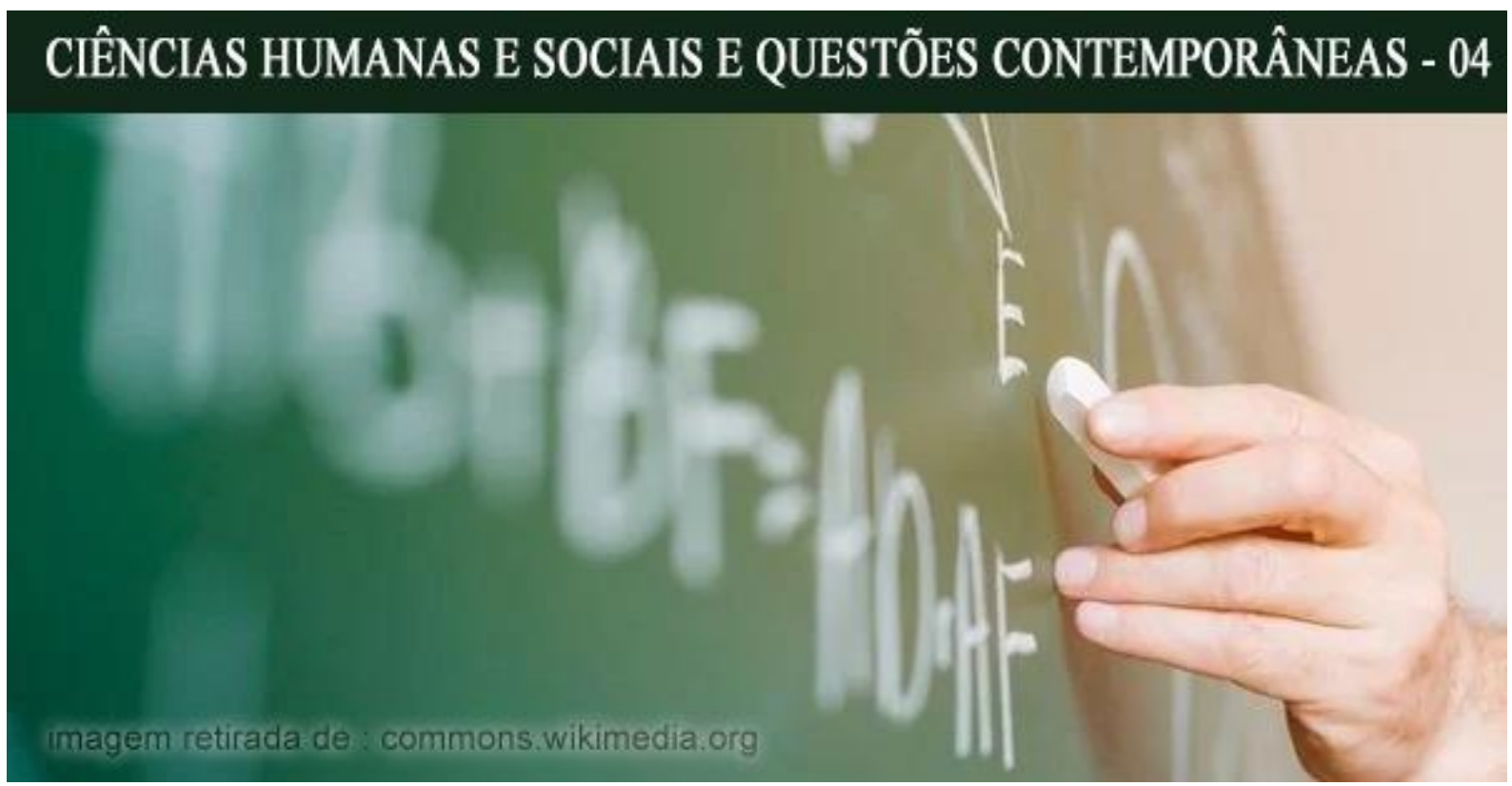

\title{
FORMAÇÃO CONTINUADA DE PROFESORES DA EDUCAÇÃo BÁSICA: IMPACTO NA APRENDIZAGEM DOS PROFESSORES E DOS ALUNOS DA REDE PÚBLICA ESTADUAL DE UBERABA
}

\author{
Rafaela Mariane Sousa Nunes da Silva \\ ORCID: https://orcid.org/0000-0002-3390-3498. \\ E-mail: rafinhamariane@hotmail.com.
}

Resumo: Este artigo é fruto de um recorte de uma dissertação de Mestrado, que buscou identificar o impacto da formação continuada na aprendizagem dos professores e dos alunos dos anos iniciais do ensino fundamental da rede pública estadual de Uberaba-MG, por meio da triangulação das pesquisas bibliográfica, documental e de campo. A análise dos dados realizou-se com auxílio do software Microsoft Excel, que permitiu uma aproximação do impacto da formação continuada na aprendizagem dos docentes atuantes nos anos iniciais dessa rede de ensino e dos alunos. Constatou-se inúmeras insatisfações dos sujeitos da pesquisa no que tange a suas formações continuadas, assim como, pouco impacto dessas na aprendizagem dos professores e dos alunos. A pesquisa aspira a contribuir com a melhoria das propostas da rede estadual de ensino de Uberaba-MG para a formação continuada dos professores e, em consequência, a melhora da qualidade da educação no município. Os resultados da pesquisa possuem um caráter fundamental para formulação de futuras políticas para formação de professores e podem servir de ponto de partida para a implementação de estratégias e ações nesse importante campo do conhecimento.

Palavras-chaves: Educação Básica. Impacto. Aprendizagem. Formação. Continuada.

\section{CONTINUING EDUCATION OF BASIC EDUCATION TEACHERS: IMPACT ON THE LEARNING OF TEACHERS AND STUDENTS OF THE UBERABA STATE PUBLIC NETWORK}

Abstract: This article is the result of an excerpt from a Master's dissertation, which sought to identify the impact of continuing education on the learning of teachers and students in the early years of elementary school in the state public network of Uberaba-MG, through the triangulation of bibliographic research, documentary and field. Data analysis was carried out with the aid of Microsoft Excel software, which allowed us to approximate the impact of continuing education on the learning of teachers working in the early years of this teaching network and students. There were numerous dissatisfactions of the research subjects with regard to their continuing education, as well as little impact on the learning of teachers and students. The research aspires to contribute to the improvement of the

\section{POLÊM!CA $\mid$ LABORE}

Polêmica - Revista Eletrônica da Uerj - Rua São Francisco Xavier, 524, $1^{\circ}$ andar bloco D, sl.1001 • Tels.: +55 21 2334-4088 / 4087 • http://www.e-publicacoes.uerj.br/index.php/polemica/index http://www.labore.uerj.br • laboreuerj@yahoo.com.br 
proposals of the state education system in Uberaba, MG, for the continuing education of teachers and, as a consequence, to improve the quality of education in the municipality. The research results have a fundamental character for the formulation of future policies for teacher education and can serve as a starting point for the implementation of strategies and actions in this important field of knowledge.

Keywords: Basic education. Impact. Learning. Continuing. Formation.

\section{Introdução}

Esse estudo se insere no projeto guarda-chuva "Formação Continuada de Professores em Minas Gerais: políticas, programas, necessidades e impactos na aprendizagem dos alunos”. O objetivo geral é identificar o impacto da formação continuada na aprendizagem dos professores e na aprendizagem dos alunos, por meio da triangulação das pesquisas bibliográfica, documental e de campo.

Os professores ocupam o terceiro lugar na escala dos subgrupos ocupacionais mais numerosos do Brasil. Segundo Barreto (2015), existe atualmente no Brasil cerca de dois milhões de professores na Educação Básica para atender cerca de 51 milhões de alunos matriculados nessa etapa de ensino, sendo $80 \%$ desses no setor público. Partindo desses dados, pode-se supor as inúmeras problemáticas que envolvem a formação desse grupo tão numeroso de profissionais e a necessidade de se olhar com cuidado, critério e com bastante rigor científico para esse importante campo disciplinar.

É sabido e igualmente reconhecido que a qualidade da educação oferecida aos alunos brasileiros passa, indiscutivelmente, pela atividade docente e, em consequência, pela sua formação, a inicial, a continuada, e impactada direta e indiretamente pelos planos de carreira, condições de trabalho, salários, valorização social, cultural, política e econômica, entre tantas outras políticas para a formação de professores, que ainda são vistas como um desafio em pleno século XXI.

Nesse sentido, serão apresentados os principais conceitos e aspectos legais da formação de professores, reflexões sobre a formação continuada em serviço e, por fim, a metodologia da pesquisa, juntamente com a análise de dados, que traçou um recorte do perfil sociodemográfico dos participantes da pesquisa e revelou o impacto da formação continuada na aprendizagem dos professores, na sala de aula e na aprendizagem dos alunos pela ótica do professorado dos anos iniciais do ensino fundamental da rede pública estadual de Uberaba, MG. Por fim, serão apresentadas as considerações finais, com alguns pontos centrais que emergiram da análise de dados e, a partir deles, sugestões para esse importante campo do conhecimento, os alcances da pesquisa e as suas limitações.

\section{POLÊM!CA $\mid$ LABORE}

Polêmica - Revista Eletrônica da Uerj - Rua São Francisco Xavier, 524, $1^{\circ}$ andar bloco D, sl.1001 • Tels.: +55 21 2334-4088 / 4087 • http://www.e-publicacoes.uerj.br/index.php/polemica/index http://www.labore.uerj.br • laboreuerj@yahoo.com.br 


\section{Formação de professores: aspectos conceituais e legais}

A formação de professores é uma área emergente de atuação profissional e de pesquisa que começa a se configurar a partir da década de $1980^{1}$ como disciplina específica. Vários autores, como Cunha (2010), Marcelo García (1999), Nóvoa (1992), Ramalho (2004), Tardif (2002), Zeichner (1992), Huberman (1995), Candau (1998), Gatti et al. (2019), Leone (2012), Mizukami (2004), entre outros, têm se dedicado ao estudo desse campo do conhecimento. No entanto, o fato desse campo ser recente e, por consequência, haver carência, hoje, de perspectiva histórica, isto se configura como um obstáculo que dificulta a análise das necessidades e consequente aprofundamento nas pesquisas.

Segundo Aquino e González (2018), a formação de professores nasceu no campo disciplinar da Didática e permanece atrelada a ela até os dias atuais, pois os referenciais teóricos da primeira são emprestados, assim como os métodos de investigação e procedimentos de análise de dados, o que facilita a confusão entre as duas disciplinas - Didática e Formação de professores - e entre seus respectivos objetos de estudo. A despeito do objeto de estudo da formação de professores, os autores indicam a falta de consenso desse objeto e a maneira como é tratado, como um dos principais problemas para a área de formação.

A Lei de Diretrizes e Bases de 1996 (LDBEN 9394/96), responsável pela definição e regularização da educação brasileira, tendo como base, os princípios da Constituição Brasileira, é um documento norteador da educação e da formação de professores, que traz a seguinte normativa sobre a formação dos professores da Educação Básica:

Consideram-se profissionais da educação escolar básica os que, nela estando em efetivo exercício e tendo sido formados em cursos reconhecidos, são: I - professores habilitados em nível médio ou superior para a docência na educação infantil e nos ensinos fundamental e médio; II - trabalhadores em educação portadores de diploma de pedagogia [...] bem como com títulos de mestrado ou doutorado nas mesmas áreas $[\ldots]$.

Parágrafo único. A formação dos profissionais da educação, de modo a atender às especificidades do exercício de suas atividades, bem como aos objetivos das diferentes etapas e modalidades da educação básica, terá como fundamentos: I - a presença de sólida formação básica [...] II - a associação entre teorias e práticas [...] III - o aproveitamento da formação e experiências anteriores, em instituições de ensino e em outras atividades (BRASIL, 1996, p. 34-35).

\footnotetext{
${ }^{1}$ Até a década de 1980, as pesquisas nessa área existiam, mas eram esparsas.

\section{POLÊM!CA $\mid$ LABORË}

Polêmica - Revista Eletrônica da Uerj - Rua São Francisco Xavier, 524, $1^{\circ}$ andar bloco D, sl.1001 • Tels.: +55 21 2334-4088 / 4087 • http://www.e-publicacoes.uerj.br/index.php/polemica/index http://www.labore.uerj.br • laboreuerj@yahoo.com.br
} 
Essa normativa traz aspectos importantes no que se refere a formação de professores da Educação Básica. O primeiro deles é que, apesar de o curso em nível superior não ser um imperativo, como deveria, para ser professor, o sujeito deverá, inevitavelmente, submeter-se a um curso de formação inicial devidamente reconhecido. Outro aspecto diz respeito à necessidade de uma formação sólida, que garanta a apropriação dos conhecimentos necessários para o exercício da docência, assim como a associação das devidas indissociáveis teoria e prática. Sobre esse último aspecto, Freire (1996, p. 25) já dizia, “A 'teoria' sem a prática vira 'verbalismo', assim como a prática sem teoria vira ativismo. No entanto, quando se une a prática com a teoria tem-se a práxis, a ação criadora e modificadora da realidade".

Nessa mesma linha de pensamento, que visa a solidez da formação por meio da apropriação dos saberes necessários e da relação entre a teoria e a prática, que Libâneo (1994, p. 27) conceitua a formação profissional de professores como "[...] um processo pedagógico, intencional e organizado, de preparação teórico-científica e técnica do professor para dirigir competentemente o processo de ensino". É justamente essa competência que se almeja nos cursos de formação docente, sejam eles, iniciais ou contínuos.

O Conselho Nacional de Educação $(\mathrm{CNE})^{2}$, por sua vez, movimentou-se em busca de uma maior organicidade para a formação de professores, incluindo a revisão das diretrizes e de outros documentos normativos acerca das formações inicial e continuada. As novas Diretrizes Curriculares Nacionais (DCN) ${ }^{3}$ definem os princípios das formações inicial e continuada dos profissionais do magistério da educação básica e apontam para uma maior organicidade nos projetos formativos, necessidade de maior articulação entre as instituições de ensino superior e de Educação Básica, definindo que essas devem contemplar:

I. Sólida formação teórica e interdisciplinar dos profissionais;

II. A inserção dos estudantes de licenciatura nas instituições de educação básica da rede pública de ensino, espaço privilegiado da práxis docente; III. O contexto educacional da região onde será desenvolvido; IV. Atividades de socialização e avaliação dos impactos;

\footnotetext{
2 “O CNE tem por missão a busca democrática de alternativas e mecanismos institucionais que possibilitem, no âmbito de sua esfera de competência, assegurar a participação da sociedade no desenvolvimento, aprimoramento e consolidação da educação nacional de qualidade" (MEC, 2018, não paginado).

3 "As Diretrizes Curriculares Nacionais são um conjunto de definições doutrinárias sobre princípios, fundamentos e procedimentos na Educação Básica que orientam as escolas na organização, articulação, desenvolvimento e avaliação de suas propostas pedagógicas" (TODOS PELA EDUCAÇÃO, 2018, não paginado).
}

\section{POLÊM!CA | LABORE}

Polêmica - Revista Eletrônica da Uerj - Rua São Francisco Xavier, 524, $1^{\circ}$ andar bloco D, sl.1001 • Tels.: +55 21 2334-4088 / 4087 • http://www.e-publicacoes.uerj.br/index.php/polemica/index http://www.labore.uerj.br • laboreuerj@yahoo.com.br 
V. Aspectos relacionados à ampliação e ao aperfeiçoamento do uso da língua portuguesa e à capacidade comunicativa, oral e escrita, como elementos fundamentais da formação dos professores e à aprendizagem de Libras;

VI. Questões socioambientais, éticas, estéticas e relativas a diversidade étnico-racial, de gênero, sexual, religiosa, de faixa geracional e sociocultural como princípios de equidade (BRASIL, 2015b, p. 23-24).

Esses princípios reforçam a LDBEN 9394/96 quando trazem a necessidade de uma sólida formação dos professores e a inserção dos sujeitos em formação nas escolas de Educação Básica, como possibilidade de relacionar, de forma consistente, a teoria e a prática, privilegiando a apropriação de saberes necessários para a prática docente.

Partindo do pressuposto de que a docência é uma ação social, construindo-se na base da ação humana, e que todos ensinam e aprendem ao longo da vida, compreende-se a polissemia da formação docente. Diferentes autores têm estudado sobre essa multiplicidade de sentidos da palavra "formação", e todos eles demonstram que esses saberes têm origens e matrizes e se constroem em diferentes lugares e tempos ao longo da vida do indivíduo - está intrinsecamente relacionada com a vida do sujeito em formação, seus motivos e necessidades.

\begin{abstract}
Se, na experiência de minha formação, que deve ser permanente, começo por aceitar que o formador é o sujeito em relação a quem me considero o objeto, que ele é o sujeito que me forma e eu, o objeto por ele formado, me considero como um paciente, que recebe os conhecimentos-conteúdos-acumulados pelo sujeito que sabe e que são a mim transferidos. Nesta forma de compreender e de viver o processo formador, eu, objeto agora, terei a possibilidade, amanhã, de me tornar o falso sujeito da "formação" do futuro objeto de meu ato formador. É preciso que, pelo contrário, desde os começos do processo, vá ficando cada vez mais claro que, embora diferentes entre si, quem forma se forma e re-forma ao formar e quem é formado forma-se e forma ao ser formado. É neste sentido que ensinar não é transferir conhecimentos, conteúdos, nem formar é a ação pela qual um sujeito criador dá forma, estilo ou alma a um corpo indeciso e acomodado (FREIRE, 1996, p. 22-23).
\end{abstract}

Pressupõe-se por meio dessa fala de Freire que a formação está diretamente ligada à relação dialética do sujeito e do objeto; que o professor, enquanto sujeito e objeto da própria formação, é ativo, que se forma, se reforma, se transforma e transforma o seu externo. Ele não recebe passivamente conhecimentos produzidos por outrem, pois é responsável pela construção do seu próprio conhecimento. A tomada de consciência da importância da formação é, logo, o primeiro passo para o desenvolvimento profissional.

Se o professor toma consciência disso, que é um sujeito ativo no seu processo de formação e que esta possui uma forte relação com o lugar e o tempo em que ela se desenvolve, e se a considerar como um processo vital, ao passar a vida inteira por processos formativos com

\title{
POLÊM!CA $\mid$ LABORE
}

Polêmica - Revista Eletrônica da Uerj - Rua São Francisco Xavier, 524, $1^{\circ}$ andar bloco D, sl.1001 • Tels.: +55 21 2334-4088 / 4087 • http://www.e-publicacoes.uerj.br/index.php/polemica/index http://www.labore.uerj.br • laboreuerj@yahoo.com.br 
objetivos diferentes, compreenderá que os espaços de formação são múltiplos. No entanto, a sociedade legitimou a escola e as universidades, enquanto espaços formais, para serem os espaços de formação para o campo profissional (CUNHA, 2015).

É sabido que o papel das instituições formadoras de professores, responsáveis pela formação inicial, assim como as escolas em que atuam esses profissionais e o poder público, em geral, responsáveis pela sua formação continuada, são de extrema importância no desenvolvimento profissional desses. Corroborando essa última afirmação, Nóvoa se mostra incisivo em uma entrevista dada à revista Nova Escola quando diz: "professor se forma na escola" (NÓVOA, 2001, não paginado).

Entendemos a escola assim, como lócus privilegiado da formação continuada, e acreditamos também que é a autonomia e as necessidades desses sujeitos em formação que contribuirão significativamente no processo de busca pelo seu aprimoramento profissional, assim como mostrará Ferry (1991, p. 43): "Formar-se nada mais é senão um trabalho sobre si mesmo, livremente imaginado, desejado e procurado, realizado através de meios que são oferecidos ou que o próprio procura".

Diante da dimensão conceitual das diferentes áreas que fundamentam a formação de professores, a mesma vai se constituindo em uma potente matriz disciplinar, com consolidação científica, de validade epistemológica permanente, com rigor de seus paradigmas, utilização de modelos e métodos de investigação próprios (MEDINA; DOMINGUEZ, 1989).

Para Gatti (2015, p. 231), a formação ideal traria,

[...] o profissional que deve poder dialogar de maneira efetiva com as novas gerações, com as crianças e jovens, despertando-as para os valores, os saberes e a riqueza dos conhecimentos que alimentam nossa civilização, levando-as a aprendizagens consistentes para sua vida pessoal, na sociedade e no mundo do trabalho.

O que leva a compreender a necessidade de se olhar a profissão docente dos profissionais da Educação Básica com um novo olhar, e de propor uma formação mais sólida, que se preocupe com os conhecimentos constituídos no campo da educação e os valores humanitários necessários para a vida em sociedade, numa “[...] perspectiva filosófica e ética e da função social própria à educação básica, à escola e aos processos de escolarização - ensinar às novas gerações o conhecimento acumulado e consolidar valores e práticas coerentes com nossa vida civil” (GATTI, 2015, p. 232).

\section{POLÊM!CA $\mid$ LABORE}

Polêmica - Revista Eletrônica da Uerj - Rua São Francisco Xavier, 524, $1^{\circ}$ andar bloco D, sl.1001 • Tels.: +55 21 2334-4088 / 4087 • http://www.e-publicacoes.uerj.br/index.php/polemica/index http://www.labore.uerj.br • laboreuerj@yahoo.com.br 
A autora supracitada discute sobre a necessidade de uma revolução no campo da formação dos docentes da Educação Básica, onde se tenha uma perspectiva com relação ao campo de conhecimentos relativos à educação e à educação escolar enquanto fatos históricossociais, que considera a inter-relação de duas vertentes do conhecimento para a área educacional:

[...] aquela que se constitui a partir das práticas educacionais na sociedade, de sua institucionalização em espaços profissionais diversos no movimento histórico dessas sociedades; e a derivada dos estudos científicos que as práticas e as demandas sociais suscitam e que acabaram por se configurar como um campo multidisciplinar de conhecimentos (GATTI, 2015, p. 234).

Dentro dessa epistemologia de formação de professores, Hofstetter e Schneuwly (2001 apud GATTI, 2015) apresentaram uma interessante perspectiva de disciplinarização, do ponto de vista histórico-social, para compreendermos a constituição do campo de investigação científica da educação com suas particularidades e conhecimentos específicos, e suas contribuições para a formação de professores. O campo de conhecimento em educação que aborda distintos setores disciplinares das Ciências da Educação, entre eles Didática, Sociologia da Educação, Política da Educação, Psicologia da Educação, História da Educação, Filosofia da Educação, Linguística e Educação, Economia da Educação, Avaliação Educacional, Gestão Escolar, Pedagogia, entre outros, com características próprias, estuda a educação em relação ao social. Esse campo plural levanta problemáticas, indaga, procura soluções, busca compreensões e contribuições mais significativas para as práticas sociais educativas.

Nesse sentido e na busca pela revolução da formação de professores, a autora propõe a integralização de duas vertentes pelos cursos de licenciatura: utilização das ciências da educação como norteadoras do trabalho educativo e à luz dos conteúdos disciplinares de áreas distintas do conhecimento humano-científico, tidos como relevantes à formação das novas gerações.

Complementando essa perspectiva da autora, apresentamos a conceituação de Marcelo García (1999, p. 26) para esse importante campo do conhecimento:

A formação de professores é a área de conhecimentos, investigação e de propostas teóricas e práticas que, no âmbito da Didática e da Organização Escolar, estuda os processos através dos quais os professores em formação ou em exercício se implicam individualmente ou em equipe, em experiências de aprendizagens através das quais adquirem ou melhoram seus conhecimentos, competências e disposições, e que lhes

\section{POLÊM!CA $\mid$ LABORE}

Polêmica - Revista Eletrônica da Uerj - Rua São Francisco Xavier, 524, $1^{\circ}$ andar bloco D, sl.1001 • Tels.: +55 21 2334-4088 / 4087 • http://www.e-publicacoes.uerj.br/index.php/polemica/index http://www.labore.uerj.br • laboreuerj@yahoo.com.br 
permite intervir profissionalmente no desenvolvimento de seu ensino, do currículo e da escola com o objetivo de melhorar a qualidade da educação que os alunos recebem.

Essa conceituação enxerga a formação docente como um processo dual, que tanto pode ser individual como entre os pares, com fins últimos na melhoria da qualidade da educação, cabendo-nos acrescentar, somente, a necessidade dos sistemas de ensino e os responsáveis pelo oferecimento da formação, de se estudar os sujeitos em formação, o que querem, como pensam, quais são suas reais necessidades nesse processo, quais são as relações que estabelecem com o contexto sociocultural, por meio de suas atividades, com seus motivos, expectativas e sentimentos.

Considera-se, logo, que a formação de professores é vista como uma área do conhecimento e investigação que estuda os processos por meio dos quais os sujeitos aprendem e desenvolvem sua capacidade profissional e também como um processo sistemático e organizado, inconcluso, que não termina nos professores, mas sim na qualidade de ensino que os alunos recebem e seus desdobramentos nas atitudes/ações e formação humana.

\section{Reflexões sobre a problemática da formação continuada}

Os investimentos nos estudos sobre a formação continuada cresceram qualitativa e quantitativamente na última década no país. Isso se justifica, entre outras explicações, pelas lacunas e deficiências, facilmente observáveis, deixadas pela formação inicial, em função da precariedade em que se encontram os cursos de licenciatura na atual conjuntura brasileira. A formação continuada refere-se a:

[...] iniciativas instituídas no período que acompanha o tempo profissional dos professores. Pode ter formatos e duração diferenciados, assumindo a perspectiva da formação como processo. Tanto pode ter origem na iniciativa dos interessados como pode inserir-se em programas institucionais. Nesse caso, os sistemas de ensino, as universidades e as escolas são as principais agências mobilizadoras dessa formação (CUNHA, 2013, p. 612).

Segundo as DCNs (2015), a formação continuada de professores tem como principal finalidade "a reflexão sobre a prática educacional e a busca de aperfeiçoamento técnico, pedagógico, ético e político do profissional docente" (DOURADO, 2015, p. 312) e leva em conta:

\section{POLÊM!CA $\mid$ LABORE}

Polêmica - Revista Eletrônica da Uerj - Rua São Francisco Xavier, 524, $1^{\circ}$ andar bloco D, sl.1001 • Tels.: +55 21 2334-4088 / 4087 • http://www.e-publicacoes.uerj.br/index.php/polemica/index http://www.labore.uerj.br • laboreuerj@yahoo.com.br 
I. os sistemas e redes de ensino, o projeto pedagógico das instituições de Educação Básica, bem como os problemas e os desafios da escola e do contexto onde ela está inserida;

II. a necessidade de acompanhar a inovação e o desenvolvimento associados ao conhecimento, à ciência e à tecnologia;

III. o respeito ao protagonismo do professor e a um espaço-tempo que lhe permita refletir criticamente e aperfeiçoar sua prática;

IV. o diálogo e a parceria com atores e instituições competentes, capazes de contribuir para alavancar novos patamares de qualidade ao complexo trabalho de gestão da sala de aula e da instituição educativa (BRASIL, 2015b, p. 34).

Essa formação deverá se dar pela oferta de atividades formativas diversas, tais como cursos de atualização e extensão, aperfeiçoamento, especialização, mestrado, doutorado que propiciem a apropriação de novos saberes e práticas.

Ainda que a necessidade da formação contínua tenha sido reconhecida nas esferas públicas e privadas, de modo geral, as iniciativas se apresentam ainda de forma descontextualizadas, centrando-se na oferta de cursos de curta duração, de caráter pontual e assistemático. Contudo, estudos e pesquisas recentes na área começaram a questionar esse tipo de formação, delineando, assim, buscas, reflexões e estudos voltados para construção de novos caminhos, onde as necessidades formativas, expectativas, interesses e motivações dos professores vão de encontro com esse processo (LEONE, 2012).

Para que os professores alcancem resultados favoráveis em sua formação, faz-se necessário compreendê-los como pessoas adultas em processo permanente de aprendizagem, os quais possuem suas próprias formas de aprender e de pensar. "A aprendizagem da pessoa adulta requer que ela desenvolva uma concepção sobre si mesma, que utilize a experiência como recurso de aprendizagem e que se motive a aprender em função dos papéis sociais que desenvolve" (VAILLANT; MARCELO GARCÍA, 2012, p. 29).

Para tanto, Ramalho e Nuñez (2011, p. 73) discutem a formação continuada como:

[...] mais que instrução ou aprendizagem de conhecimentos e formação de habilidades e de competências, pois inclui, entre outras coisas, interesses, necessidades, intenções, motivações, caráter, capacidades, condutas, crenças, atitudes e valores. [...] A apropriação da cultura profissional supõe não só o conhecimento como também sua aplicação na solução de situações-problema próprias da profissão em contextos específicos.

Esses autores vão ao cerne do problema quando discutem a formação continuada como algo maior do que a apropriação de conhecimentos. Acredita-se, assim como eles, que os “"[...] interesses, necessidades, intenções, motivações, caráter, capacidades, condutas, crenças,

\section{POLÊM!CA $\mid$ LABORE}

Polêmica - Revista Eletrônica da Uerj - Rua São Francisco Xavier, 524, $1^{\circ}$ andar bloco D, sl.1001 • Tels.: +55 21 2334-4088 / 4087 • http://www.e-publicacoes.uerj.br/index.php/polemica/index http://www.labore.uerj.br • laboreuerj@yahoo.com.br 
atitudes e valores [...]" dos professores precisam ir ao encontro com a proposta de formação continuada. Nesse mesmo sentido, Fullan (1991, p. 117) reflete que "[...] as mudanças na educação dependem do que pensam e fazem os professores, algo tão simples e, por sua vez, tão complexo". Não se pretende aqui colocar todos os problemas em relação à educação em cima do professor; claro que existe uma multiplicidade de problemas que escapam das mãos deles, mas se faz necessário reforçar a reflexão sobre a importância da formação de professores em uma relação indissociável com suas necessidades internas.

Ao se fazer uma busca sistemática na literatura brasileira, de pesquisas referentes ao significado da formação para aqueles professores que já estão atuando, será verificado que poucos são os estudos preocupados com o cerne do problema, no que tange a formação de professores. Nesse sentido, Ramalho e Nuñez (2011, p. 71), acrescentam:

O desenvolvimento profissional tem que estar associado a processos sucessivos de autorregulação da formação como um tipo específico de atividade, baseado na reflexão crítica, na compreensão e no controle do que se pensa, do que se sente, do que se faz e do que lhe é necessário para mudar.

O Ministério da Educação define esse importante campo do conhecimento como sendo um:

[...] processo contínuo de permanente desenvolvimento, o que pede do professor disponibilidade para a aprendizagem; da formação, que o ensine a aprender; e do sistema escolar no qual ele se insere como profissional, condições para continuar aprendendo. Ser profissional implica ser capaz de aprender sempre (BRASIL, 2002, p. 63).

É nesse sentido que, em concordância com os autores, entende-se que, apesar de todo conhecimento construído no que se refere à formação continuada de professores e de todo aparato legal para tal, é fato que ainda se faz recorrente programas de formação nos moldes tradicionais, constituídos por cursos sem contextualização e sem sentido e significação para os professores. A literatura se mostra consensual quanto aos objetivos da formação continuada, que é, entre outros, propor mudanças na ação educativa para que melhore qualitativamente o ensino, com fins a assegurar uma educação de qualidade. No entanto, mesmo com todos os estudos, pesquisas e legislações, não se consegue chegar aos objetivos, o que leva a inferir que falta ouvir o que os principais responsáveis por essa formação pensam e sentem, além de garantir a efetivação das políticas públicas para a formação de professores.

\section{POLÊM!CA $\mid$ LABORE}

Polêmica - Revista Eletrônica da Uerj - Rua São Francisco Xavier, 524, $1^{\circ}$ andar bloco D, sl.1001 • Tels.: +55 21 2334-4088 / 4087 • http://www.e-publicacoes.uerj.br/index.php/polemica/index http://www.labore.uerj.br • laboreuerj@yahoo.com.br 
Apoiados na Teoria Histórico-Cultural, definiu-se a formação continuada de professores como sendo um processo contínuo, inconcluso, que precisa ser organizado e oferecido de forma sistemática, que possui componentes subjetivos, como valores, interesses, motivações, necessidades, crenças e objetivos. Esse processo pode ser realizado individualmente ou em grupo e, fazendo sentido para o sujeito da formação, vai proporcionar a construção dos conhecimentos necessários para a prática docente, abrindo possibilidades para o docente refletir sobre sua própria prática pedagógica, implicando em mudanças, inovações e desenvolvimento, que vai impactar diretamente na qualidade da educação oferecida.

Parte-se do princípio que a formação continuada, comprometida com o desenvolvimento profissional do professor em sua integridade, propicia a construção da aprendizagem do mesmo e, em consequência, de seus alunos. Por aprendizagem, compreende-se a apropriação ativa do indivíduo da experiência sociocultural. Nesse sentido, Tabille e Jacometo (2017) refletem:

[...] a aprendizagem é como uma construção pessoal resultante de um processo experimental, inerente à pessoa e que se manifesta por uma modificação de comportamento. Sabe-se que a aprendizagem é um fenômeno extremamente complexo, envolvendo aspectos cognitivos, emocionais, orgânicos, psicossociais e culturais (TABILLE; JACOMETO, 2017, p. 3)

Sabe-se que várias são as Teorias da Aprendizagem que sustentam as mais diferentes concepções de como a aprendizagem acontece, no entanto, é na Teoria Histórico-Cultural que se fundamentam esses estudos. Logo, apresenta-se a concepção do pioneiro dessa teoria:

\footnotetext{
Não há necessidade de sublinhar que a característica essencial da aprendizagem é que dá lugar à área do desenvolvimento potencial, isto é, faz nascer, estimula e ativa, na criança, processos internos de desenvolvimento no quadro das interrelações com outros que, em seguida, são absorvidas, no curso do desenvolvimento interno, tornando-se aquisições próprias da criança... A Aprendizagem, por isso, é um momento necessário e universal para o desenvolvimento, na criança, daquelas características humanas não naturais, mas formadas historicamente (VYGOTSKY, 1973, p. 161).
}

Por meio dessa fala de Vygotsky (1973), compreende-se a importância do meio e das relações para o processo de aprendizagem, tal como a imprescindibilidade da aprendizagem para o desenvolvimento das máximas potencialidades humanas. Compreende-se também que a aprendizagem implica em mudanças, transformações, inovações etc.

Parte-se da concepção que se a formação impacta na aprendizagem dos professores, logo, ela impactará também, na aprendizagem de seus alunos, pois conceitos serão apreendidos,

\section{POLÊM!CA $\mid$ LABORE}

Polêmica - Revista Eletrônica da Uerj - Rua São Francisco Xavier, 524, $1^{\circ}$ andar bloco D, sl.1001 • Tels.: +55 21 2334-4088 / 4087 • http://www.e-publicacoes.uerj.br/index.php/polemica/index http://www.labore.uerj.br • laboreuerj@yahoo.com.br 
repensados, reformulados ou até mesmo desconstruídos para serem reconstruídos, possibilidades de se repensar e refletir sobre a prática pedagógica surgirão, assim como transformações acontecerão, visto que os professores poderão tomar consciência do seu importante papel de promover a aprendizagem e o desenvolvimento mental de seus alunos, com alto nível de abstração, em conexão com a realidade concreta (FREITAS, 2016).

A palavra impacto, originária do latim impactus, pode ser definida pelo Dicionário Online de Português como "[...] o que produz um efeito muito forte em [...]" (IMPACTO, 2019), sendo assim, reformula-se a pergunta norteadora para uma melhor apropriação dessa: qual o efeito forte que a formação continuada produz na aprendizagem dos professores e, em consequência, na aprendizagem de seus alunos?

\section{Metodologia da pesquisa}

Em consonância com a análise das necessidades formativas, optou-se por uma abordagem mista, utilizando-se da pesquisa quali-quantitativa, por almejar uma análise mais aprofundada do objeto de pesquisa, acreditando que uma complementa a outra. Nesse sentido, a investigação aqui proposta se realizou utilizando-se de três modalidades de pesquisa, que fazse saber: a pesquisa bibliográfica, a pesquisa documental e a pesquisa de campo.

Em um primeiro momento, utilizou-se a pesquisa bibliográfica.

A pesquisa bibliográfica é desenvolvida com base em material já elaborado, constituído principalmente de livros e artigos científicos. Embora em quase todos os estudos seja exigido algum tipo de trabalho dessa natureza, há pesquisas desenvolvidas exclusivamente a partir de fontes bibliográficas (GIL, 2002, p. 44).

O recorte para a seleção do acervo bibliográfico compreendeu os textos publicados a partir dos anos 90, quando as discussões em torno das políticas de formação de professores começaram a ganhar espaço no cenário brasileiro.

Para análise dos resultados dessa parte da pesquisa, utilizou-se a Ficha Resumo de Conteúdo como instrumento de coleta e de análise da informação bibliográfica. O objetivo das fichas é “a condensação do conteúdo, expondo ao mesmo tempo tanto as finalidades e metodologia quanto os resultados obtidos e as conclusões da autoria, permitindo a utilização em trabalhos científicos e dispensando, portanto, a leitura posterior do texto original" (MARKONI; LAKATOS, 2003, p. 68).

\section{POLÊM!CA $\mid$ LABORE}

Polêmica - Revista Eletrônica da Uerj - Rua São Francisco Xavier, 524, $1^{\circ}$ andar bloco D, sl.1001 • Tels.: +55 21 2334-4088 / 4087 • http://www.e-publicacoes.uerj.br/index.php/polemica/index http://www.labore.uerj.br • laboreuerj@yahoo.com.br 
Em um segundo momento, recorreu-se à pesquisa documental para um estudo dos documentos oficiais que dispõem de políticas para a formação de professores no Brasil, em nível federal. A pesquisa documental se justifica pela importância de se conhecer o que as políticas públicas trazem de positivo, quais são as confluências, incoerências e limitações. Oliveira (2007, p. 69) afirma que a pesquisa documental é um tipo de "estudo direto em fontes científicas, sem precisar recorrer diretamente aos fatos/fenômenos da realidade empírica". Como instrumento de coleta e análise da informação documental, usou-se a Ficha de Análise Documental.

O terceiro momento consistiu na pesquisa de campo, que se realizou por meio de aplicação de questionário destinado aos sujeitos da pesquisa: uma amostra de professores dos anos iniciais da Educação Básica da rede de ensino estadual de Uberaba-MG. O questionário foi estruturado em três blocos, a saber: a) Bloco I: Dados sociodemográficos; b) Bloco II: O impacto da formação na aprendizagem dos professores; c) Bloco III: O impacto da formação na sala de aula e na aprendizagem dos alunos.

Segundo Barbier (apud Rodrigues, 2006, p. 106), “[...] os instrumentos de investigação [de necessidades] não visam a produção de informações, mas a expressão das perspectivas (desejos, dificuldades, expectativas, interesses, objetivos [...] dos intervenientes identificados". Logo, compreende-se que a seleção dos instrumentos não se dá de forma aleatória, mas sim de forma rigorosa aos princípios subjacentes.

\section{Amostra dos professores}

Para a seleção dos participantes da pesquisa, tomou-se como referência os professores da Educação Básica da rede estadual de ensino de Uberaba- MG que estavam ativos em sala de aula, no ensino regular, atuando no Ensino Fundamental I, no ano de 2019.

A cidade de Uberaba contava, em 2019, com vinte e três (23) escolas nessa rede de ensino, que atendem os anos iniciais do Ensino Fundamental, segundo dados do Índice de Desenvolvimento da Educação Básica (IDEB) ${ }^{4}$. Dessas escolas, selecionamos as três (3) com o maior número de turmas e, consequentemente, com maior número de professores regentes de turma e também de alunos. São elas: 1) Escola Estadual Brasil (30 turmas); 2) Escola Estadual

\footnotetext{
${ }^{4}$ Foi criado em 2007, pelo Instituto Nacional de Estudos e Pesquisas Educacionais Anísio Teixeira (INEP), com o objetivo de avaliar a qualidade do aprendizado nacional, para assim, estabelecer metas que visem à melhoria do ensino. A quantidade e a relação de escolas estaduais foram retiradas do site do IDEB (BRASIL, 2018b).
}

\section{POLÊM!CA $\mid$ LABORE}

Polêmica - Revista Eletrônica da Uerj - Rua São Francisco Xavier, 524, $1^{\circ}$ andar bloco D, sl.1001 • Tels.: +55 21 2334-4088 / 4087 • http://www.e-publicacoes.uerj.br/index.php/polemica/index http://www.labore.uerj.br • laboreuerj@yahoo.com.br 
Fidélis Reis (28 turmas); 3) Escola Estadual Dom Eduardo (20 turmas). Não atingido a amostra pretendida, recorreu-se à quarta escola, incluída pelo número de turmas/professores necessários para atingir a amostra pretendida, de $25 \%$ do total, já que nas três selecionadas previamente, não se conseguiu chegar nesse número.

Selecionadas as escolas, selecionou-se os professores, que corresponderam a $\operatorname{todos}^{5}$ do primeiro ao quinto ano que estivessem atuando na regência de turmas regulares, que não estivessem afastados da sala por quaisquer motivos que fossem, que aceitassem participar voluntariamente da pesquisa e assinassem o Termo de Consentimento Livre e Esclarecido.

Assim, foram selecionados $25 \%$ do total de 254 (duzentos e cinquenta e quatro) professores atuantes como regentes de turmas regulares dos anos iniciais do Ensino Fundamental da rede pública estadual de Uberaba-MG; logo, 64 (sessenta e quatro) professores.

Apesar das desvantagens do questionário, como ausência de diálogo, falta de controle das condições em que as respostas são elaboradas (LEONE, 2012), ele ainda é o instrumento mais utilizado nas pesquisas sobre as necessidades formativas - segundo autores como Silva (2000) e Rodrigues (2006) -, principalmente pela possibilidade de se abranger uma população maior, visto que outro tipo de técnica não a permite e é o meio mais indicado para nos aproximar do discurso do sujeito que, apesar de saber que a palavra não é cópia fidedigna de suas necessidades formativas, foi traduzido por indicadores aproximativos, ao considerarmos as satisfações, insatisfações, dificuldades, motivações, desejos e anseios.

\section{Metodologia de análise de dados}

Como anteriormente explicado, as Fichas Resumo de Conteúdo e de Análise Documental são instrumentos que permitem sistematizar tanto a coleta como a análise dos dados bibliográficos e documentais. Essa análise foi interpretativa, hermenêutica e crítica das fontes consultadas, por meio do cotejo e cruzamento entre elas.

Os dados dos questionários foram levantados, tabelados e analisados com auxílio do Excel, na forma de porcentagem. Para nos referirmos às escolas onde os questionários foram aplicados, utilizamos as seguintes nomenclaturas: A, B, C e D. Para se referir aos sujeitos,

\footnotetext{
5 Para conseguirmos abranger os $25 \%$ da classe, precisamos fazer a pesquisa com todos ou quase todos os professores dos anos iniciais das escolas selecionadas.

\section{POLÊM!CA $\mid$ LABORE}

Polêmica - Revista Eletrônica da Uerj - Rua São Francisco Xavier, 524, $1^{\circ}$ andar bloco D, sl.1001 • Tels.: +55 21 2334-4088 / 4087 • http://www.e-publicacoes.uerj.br/index.php/polemica/index http://www.labore.uerj.br • laboreuerj@yahoo.com.br
} 
utilizou-se a letra "P" seguida do número do questionário respondido, com vistas a garantir o anonimato dos participantes da pesquisa.

Para análise desse questionário, agrupamos os resultados da escala likert em duas amplitudes. Essa escala é uma metodologia de pesquisa que apresenta questões com afirmações autodescritivas e as respostas possuem uma escala de pontos com descrições verbais que contemplam extremos (Muito Baixo, Baixo, Médio, Alto e Muito Alto). Nesse estudo, elencamos uma escala de cinco lugares em duas amplitudes. A primeira corresponde aos segmentos Muito Baixo, Baixo e Médio, enquanto que a segunda amplitude corresponde aos segmentos Alto e Muito Alto. Importante esclarecer o agrupamento do segmento Médio à primeira amplitude, dentro do segmento inferior da escala LIKERT, porque parte-se do princípio que, em se tratando de um campo tão importante como a formação de professores, não podemos admitir menos que alto em se tratando da sua satisfação com suas próprias formações. Quando a satisfação é abaixo de 79\%, consideramos ruim; entre 80 e $89 \%$, aceitável e; entre 90 e 100\%, é uma satisfação ótima, desejável.

A análise cruzada entre as informações das pesquisas documental e bibliográfica e a análise percentual do questionário conduziram à elaboração de conclusões valiosas sobre as necessidades de formação continuada da amostra com que se trabalhou na pesquisa.

\section{Análise dos dados: um recorte do perfil sociodemográfico}

Todo ponto de vista é a vista de um ponto. [...] Cada um lê com os olhos que tem. E interpreta a partir de onde os pés pisam. Todo ponto de vista é a vista de um ponto.

Para entender como alguém lê, é necessário saber como são seus olhos e qual é a sua visão de mundo. [...] Isso faz da compreensão sempre uma interpretação. Leonardo Boff

O primeiro bloco do questionário permitiu traçar o perfil sociodemográfico dos professores dos anos iniciais da rede pública estadual de Uberaba-MG, com dados sobre sexo, anos de experiência na docência, formação acadêmica, níveis de atuação e se desempenharam ou não funções de gestão nos últimos cinco anos.

No que tange ao sexo, esse grupo segue a tendência da categoria, composta majoritariamente por mulheres, nesse caso, $100 \%$ se declararam do sexo feminino. Esses dados

\section{POLÊM!CA $\mid$ LABORE}

Polêmica - Revista Eletrônica da Uerj - Rua São Francisco Xavier, 524, $1^{\circ}$ andar bloco D, sl.1001 • Tels.: +55 21 2334-4088 / 4087 • http://www.e-publicacoes.uerj.br/index.php/polemica/index http://www.labore.uerj.br • laboreuerj@yahoo.com.br 
estão em coerência com o perfil nacional traçado por Gatti e Barreto (2009), quando demonstraram que a categoria docente era composta, em 2006 , em $83,1 \%$ por mulheres.

Quanto à experiência docente, dos 64 respondentes, apenas 3 se encontram na fase que Huberman (1995) denominou de entrada na carreira, considerada por vários autores, como a principal fase do ciclo de desenvolvimento profissional, que corresponde aos cinco primeiros anos de experiência na docência. Os outros 61 sujeitos possuem mais de cinco anos de experiência na docência, sendo o intervalo entre 6 e 15 anos o mais frequente. Esse último intervalo corresponde à fase que consideramos mais positiva dos ciclos do desenvolvimento profissional, estipulados por Huberman (1995), que diz respeito à fase da diversificação (ou ativismo), caracterizada pela diversificação das aulas pelo professor, que adota novos métodos de ensino, materiais didáticos, dinamiza as aulas, agrupa os alunos de formas diferentes e estabelece novas formas de avaliação. Nessa fase, os professores se mostram mais motivados e empenhados, o que impacta positivamente no processo ensino-aprendizagem. Sendo assim, inferiu-se que a variável "experiência docente" é um aspecto positivo desse grupo.

A meta 15 do Plano Nacional de Educação 2014-2024 (BRASIL, 2014), que define os objetivos e metas para o ensino em todos os níveis a serem executados nesse período, estabelece a formação do professor em nível superior, obtida em curso de licenciatura na área de conhecimento em que atua, em consonância com a LDBEN 9.394/96, no prazo de um ano após a vigência da Lei. Essa estabelece o imperativo da formação em nível superior para os professores da Educação Básica e os dados da pesquisa nos revelam que esse grupo de professores da rede estadual de ensino está em consonância com a normativa legal, visto que $100 \%$ desses possuem licenciatura na área do conhecimento em que atuam, ou seja, Pedagogia.

Comparando com os dados nacionais, tomando como base o Relatório do $2^{\mathrm{o}}$ ciclo de monitoramento das metas do PNE 2014-2024 (BRASIL, 2018a), veremos que, se tratando da Meta 15, indicador 15b (Percentual de docências nos anos iniciais do ensino fundamental de professores com formação superior adequada à área de conhecimento que lecionam, por Brasil, grande região, unidade da Federação e município), a amostra está acima do nível nacional, que é 59,0 .

\section{POLÊM!CA $\mid$ LABORE}

Polêmica - Revista Eletrônica da Uerj - Rua São Francisco Xavier, 524, $1^{\circ}$ andar bloco D, sl.1001 • Tels.: +55 21 2334-4088 / 4087 • http://www.e-publicacoes.uerj.br/index.php/polemica/index http://www.labore.uerj.br • laboreuerj@yahoo.com.br 
Figura - 1: Percentual de docências nos anos iniciais do Ensino Fundamental de professores com formação superior adequada à área de conhecimento que lecionam, por Brasil, grande região, unidade da Federação e município

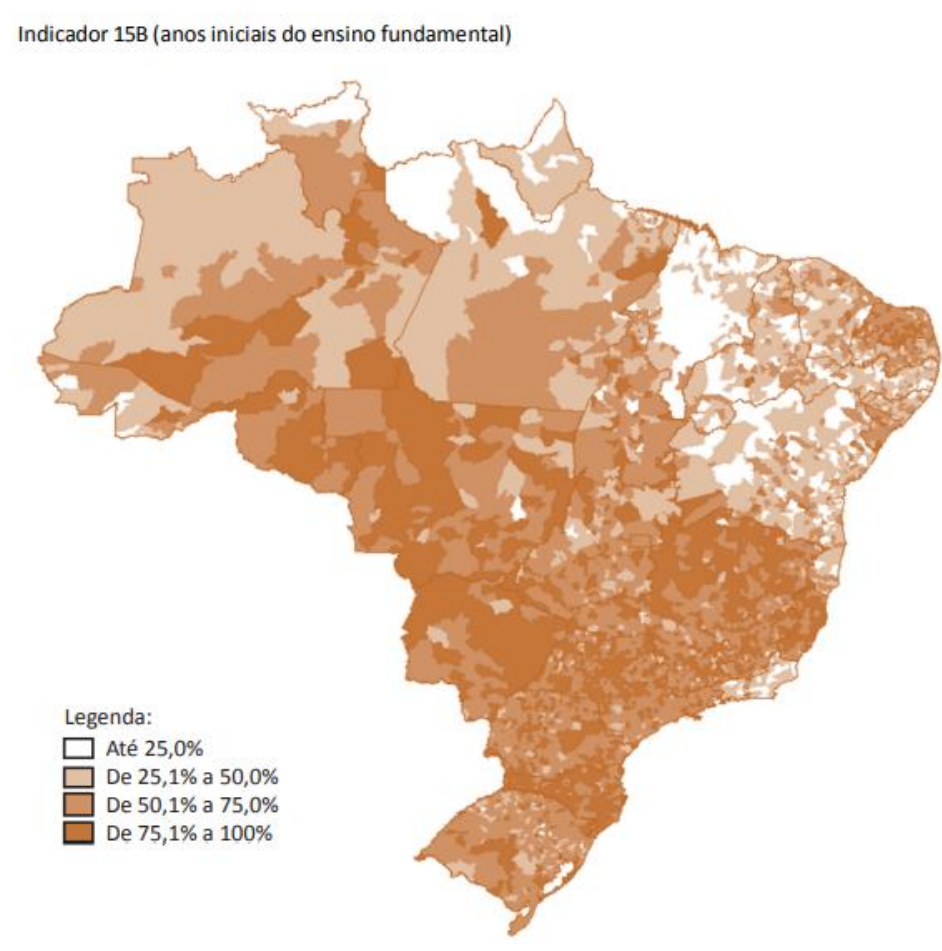

\begin{tabular}{|c|c|c|}
\hline & UF & $\begin{array}{c}\% \\
\text { docências }\end{array}$ \\
\hline \multirow{8}{*}{$\begin{array}{l}\text { पूँ } \\
\text { ò }\end{array}$} & Acre & 64,0 \\
\hline & Amapá & 39,2 \\
\hline & Amazonas & 66,4 \\
\hline & Pará & 47,4 \\
\hline & Rondônia & 77,1 \\
\hline & Roraima & 58,8 \\
\hline & Tocantins & 60,7 \\
\hline & Total & 56,6 \\
\hline \multirow{10}{*}{ 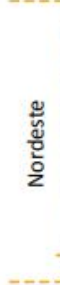 } & Alagoas & 43,6 \\
\hline & Bahia & 42,6 \\
\hline & Ceará & 45,8 \\
\hline & Maranhão & 28,3 \\
\hline & Paraiba & 51,2 \\
\hline & Pernambuco & 37,4 \\
\hline & Piauí & 44,8 \\
\hline & Rio Grande do Norte & 66,6 \\
\hline & Sergipe & 63,3 \\
\hline & Total & 43,1 \\
\hline \multirow{5}{*}{ 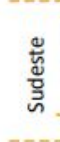 } & Espírito Santo & 77,1 \\
\hline & Minas Gerais & 74,2 \\
\hline & Rio de Janeiro & 37,1 \\
\hline & São Paulo & 72,9 \\
\hline & Total & 66,3 \\
\hline \multirow{4}{*}{$\bar{ज}$} & Paraná & 70,8 \\
\hline & Rio Grande do Sul & 60,8 \\
\hline & Santa Catarina & 77,9 \\
\hline & Total & 69,1 \\
\hline \multirow{5}{*}{ 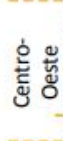 } & Distrito Federal & 70,6 \\
\hline & Goiás & 66,5 \\
\hline & Mato Grosso & 77,6 \\
\hline & Mato Grosso do Sul & 75,8 \\
\hline & Total & 71,5 \\
\hline \multicolumn{2}{|c|}{ Brasil } & 59,0 \\
\hline
\end{tabular}

Fonte: Elaborada pela Dired/Inep, 2018 (BRASIL, 2018a).

Cruzando esses dados com as notas do IDEB (BRASIL, 2018a), tomando como referência os estados com maiores números de licenciados na área do conhecimento em que atuam (Santa Catarina - Nota IDEB: 6,5; Mato Grosso - Nota IDEB: 5,9; Espírito Santo - Nota IDEB: 6,0) e os estados com menores números (Maranhão - Nota IDEB: 4,8; Rio de Janeiro Nota do IDEB: 5,8; Pernambuco - Nota do IDEB: 5,2) veremos que, em se tratando dos anos iniciais, as notas e a formação acadêmica dos professores apresentam uma tímida relação entre si. Ou seja, os estados com maior número de professores formados em nível superior na área de atuação são os que apresentam as maiores notas no IDEB. Essa tímida relação nos leva a inferir que a formação acadêmica do professor impacta sim na qualidade da educação oferecida nos anos iniciais, mesmo que não seja com o impacto esperado.

Minas Gerais está entre os seis estados com maior número de professores dos anos iniciais com formação em nível superior adequado à área de conhecimento que lecionam e entre os cinco primeiros estados com as maiores notas no IDEB.

\section{POLÊM!CA $\mid$ LABORE}

Polêmica - Revista Eletrônica da Uerj - Rua São Francisco Xavier, 524, $1^{\circ}$ andar bloco D, sl.1001 • Tels.: +55 21 2334-4088 / 4087 • http://www.e-publicacoes.uerj.br/index.php/polemica/index http://www.labore.uerj.br • laboreuerj@yahoo.com.br 
Ainda em se tratando da formação acadêmica, importante relembrar também da meta 16 do PNE 2014-2024, que estabelece que 50\% de professores da Educação Básica estejam com pós-graduação lato sensu ou stricto sensu até 2024 (BRASIL, 2014). É necessário dizer aqui que a Secretaria Estadual de Educação de Minas Gerais (SEEMG) não possui estratégias concretas para cumprimento dessa lei, tampouco incentivos; no entanto, deparar com mais de $80 \%$ dessa população portadora de diploma de pós-graduação, permite-nos inferir que os professores estão sim preocupados com suas próprias formações e consequente desenvolvimento profissional.

É sabido que essa rede de ensino aceita professores com licença para trabalhar, na condição de designado, contudo, o resultado da pesquisa mostra uma superação positiva nesse quesito, quando se verifica que nenhum dos sujeitos da pesquisa encontra-se na condição de estudante.

Se mais de $95 \%$ do total de participantes possui acima de cinco anos de experiência na docência, $100 \%$ é graduado e mais de $80 \%$ possui pós-graduação, supõe-se então que possuem uma bagagem/experiência profissional sólida e de alto nível cultural e científico. Logo, pressupõe-se que é um grupo com idoneidade para a função e portadores dos saberes necessários para a complexidade da prática docente.

Esses últimos dados, no entanto, não estão em consonância com a possibilidade do sujeito em desempenhar funções de gestão, visto que mais de $80 \%$ dos participantes não desempenharam nenhuma função de gestão nos últimos cinco anos, levando-nos a considerar que a maioria dos professores dedicam sua vida toda única e exclusivamente à sala de aula. As Diretrizes Curriculares Nacionais impõem que "[..] a formação inicial capacite esse profissional para o exercício da docência e da gestão educacional e escolar na educação básica" (BRASIL, 2015b, p. 28). Se essa mobilidade na carreira não existe, qual o motivo de prever uma lei de formação polivalente?

Parte-se do princípio que o professor precisa ter mobilidade na carreira, conhecer e explorar as diferentes funções de gestão que lhes são possíveis. A ausência dessa mobilidade recai na limitação de perspectivas profissionais e consequente precariedade do trabalho. $\mathrm{O}$ professor pode atuar não somente em funções de gestão, como também na própria formação de professores, como formador de formadores, o que pode impactar na motivação desse sujeito e na criação de sentido para entrar em atividade e se desenvolver profissionalmente.

\section{POLÊM!CA $\mid$ LABORE}

Polêmica - Revista Eletrônica da Uerj - Rua São Francisco Xavier, 524, $1^{\circ}$ andar bloco D, sl.1001 • Tels.: +55 21 2334-4088 / 4087 • http://www.e-publicacoes.uerj.br/index.php/polemica/index http://www.labore.uerj.br • laboreuerj@yahoo.com.br 
O artigo 62 da LDBEN 9.394/96 é incisivo quando trata da formação continuada em serviço:

Parágrafo único. Garantir-se-á formação continuada para os profissionais a que se refere o caput, no local de trabalho ou em instituições de educação básica e superior, incluindo cursos de educação profissional, cursos superiores de graduação plena ou tecnológicos e de pós-graduação. (Incluído pela Lei nº 12.796, de 2013) (BRASIL, 1996).

Nesse sentido, muito chamou a atenção a resposta de duas participantes quando disseram que não participaram, nos últimos 5 anos de atividades oficiais/institucionais de formação continuada de professores (cursos de formação, oficinas, grupos de estudo e pesquisa, seminários, projetos de inovação e outras). Elaborou-se algumas hipóteses, sem possibilidades de verificação: primeiro, as participantes não quiseram responder o questionário todo e assinalaram que não participaram para terminarem de "responder" mais rápido; segundo, não sabem o que significa e nem para que serve a formação continuada em serviço. Nesse último caso, importante dizer que os profissionais da rede estadual denominam o momento de formação continuada de módulo, o que justifica essa hipótese. Uma dúvida de algumas professoras da segunda escola em que foi aplicado o questionário era justamente sobre isso: o que é formação continuada?

Mesmo que a formação continuada não esteja sendo ofertada com a qualidade que merece, e que esse Horário de Trabalho Pedagógico Coletivo (HTPC) venha se tornando um espaço burocrático, de prestação de contas ao governo e à sociedade, muitas das vezes, manipulado pelos gestores para atender suas necessidades imediatas (FIORENTINI; CRECCI, 2012), ele já faz parte do marco legal e, inclusive, os professores recebem por ele. Por isso, e partindo também da realidade que todos os questionários foram aplicados no momento de formação continuada, as respostas dessas duas participantes não estão coerentes com a realidade.

Partindo do contexto em que a pesquisa foi desenvolvida, destinada exclusivamente aos professores dos anos iniciais, logo, todos os respondentes estavam atuando nesse nível de ensino no momento da aplicação do questionário. Dos 64 participantes da pesquisa, $100 \%$ estão atuando no ensino fundamental e desses, 26,6\% conciliam a educação infantil, 3,1\% o ensino médio e $3,1 \%$ o ensino superior. Sabemos também que grande parte desses professores fazem dobra de turno ou possuem duas matrículas nesse mesmo nível de ensino, devido aos baixos

\section{POLÊM!CA $\mid$ LABORE}

Polêmica - Revista Eletrônica da Uerj - Rua São Francisco Xavier, 524, $1^{\circ}$ andar bloco D, sl.1001 • Tels.: +55 21 2334-4088 / 4087 • http://www.e-publicacoes.uerj.br/index.php/polemica/index http://www.labore.uerj.br • laboreuerj@yahoo.com.br 
salários, como possibilidade de uma vida financeira mais estável, o que nos leva a inferir que se situa nessa alta demanda de trabalho, um dos motivos da precarização da profissão docente, que pode, muitas das vezes, levar ao adoecimento do profissional.

\begin{abstract}
A profissão docente é uma das profissões mais vulneráveis a fatores de stress como: alto nível de exigência, excesso de tarefas e responsabilidades, tempo limitado, sobrecarga de trabalho, falta de qualidade de vida, baixo salário, desvalorização profissional e precariedade do sistema de trabalho (FREITAS; CASTRO, 2015, p. $80)$.
\end{abstract}

Está na natureza docente a sobrecarga de trabalho, visto que além da aula ministrada em sala de aula, o professor, profissional de um ambiente de alta exigência, se vê na obrigação de desenvolver diferentes papéis, como, por exemplo, "ser amigo" dos alunos, atendendo suas necessidades pessoais, e suprir, muitas das vezes, o espaço do convívio familiar (BRAND, 2010). Precisa ainda desenvolver tarefas extraclasse, participar de reuniões administrativas e de cunho formativo, e se contentar com a desvalorização e a precariedade do seu trabalho, que impacta diretamente em sua qualidade de vida. Partindo do contexto dessa pesquisa que possui um grande número de professores em dobra de turno ou no uso de duas matrículas, surge uma preocupação com a saúde desse grupo, visto que esses fatores são responsáveis pelo adoecimento de muitos profissionais da classe.

Uma pesquisa realizada por Freitas e Castro (2015), em coerência com outras pesquisas realizadas na área, como de Gomes e Brito (2006); Miller (1992), Dejours (1988), sobre as principais doenças que acometem a saúde dos professores, constatou-se que entre os principais agravos estão: estresse crônico, depressão, síndrome neurótica do trabalho, fadiga mental e psicológica, burnout e distúrbios osteomusculares. A maior incidência está na saúde mental desse grupo de professores, resultando em índices altos de absenteísmo e solicitação de licença médica para tratamento de saúde, levando-nos a inferir que se faz necessário iniciativas governamentais que se preocupem com a prevenção de agravos e a promoção da saúde dessa categoria profissional.

\title{
O impacto da formação continuada na aprendizagem de professores
}

O terceiro bloco do questionário privilegiou questões referentes ao impacto da formação continuada na aprendizagem dos professores. Vários autores têm se dedicado a pesquisar os saberes necessários para a complexidade da prática docente, tais como Tardif (2002), Marcelo

\section{POLÊM!CA $\mid$ LABORE}

Polêmica - Revista Eletrônica da Uerj - Rua São Francisco Xavier, 524, $1^{\circ}$ andar bloco D, sl.1001 • Tels.: +55 21 2334-4088 / 4087 • http://www.e-publicacoes.uerj.br/index.php/polemica/index http://www.labore.uerj.br • laboreuerj@yahoo.com.br 
García (1999), Mizukami (2004), entre outros. Para apropriação de tais saberes, espera-se que as formações continuadas ofereçam subsídios para a construção desses conhecimentos e a reflexão sobre a práxis do professor diante de tais horizontes, com possibilidades de se repensar e ressignificar a teoria e a prática em sala de aula. Em outras palavras, espera-se que os conteúdos contemplados nas formações continuadas impactem na aprendizagem dos professores.

Partindo do pressuposto que o saber docente é composto por diversos saberes, definido por Tardif (2002, p. 36) como um saber “[...] plural, formado pelo amálgama, mais ou menos coerente, de saberes oriundos da formação profissional e de saberes disciplinares, curriculares e experenciais", acreditamos que ele deva contemplar todo o acervo de conhecimentos que o docente necessita para promover a aprendizagem de seus alunos.

Analisando os dados da pesquisa, deparou-se com as questões: "convicção de que todos os alunos podem aprender desde que as condições sejam favoráveis para o alcance dos

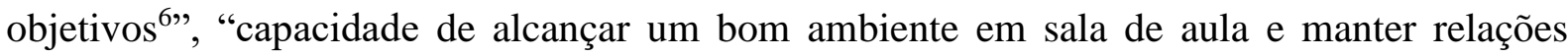
positivas com os alunos" e "consciência da importância das relações com as famílias e com o entorno social dos alunos, atuando para que essas relações sejam positivas.”, compreendendo o grupo de maior impacto na aprendizagem dos professores, alcançando o percentual de 58,9\%, $56,1 \%$ e 52,6\%, respectivamente. Esses três itens se confluem ao tratar do ambiente da sala de aula e as relações professor-aluno e professor-aluno-família, tão importantes no processo ensino-aprendizagem.

As salas de aula são compostas por uma multiplicidade incalculável de problemas, os quais, muitas das vezes, são ignorados pelos professores pelos mais diferentes motivos. Esses últimos, abarrotados de serviço e com não menos problemas, acabam ignorando as individualidades presentes na pluralidade. O intuito aqui não é, nem de longe, julgar esses profissionais no cerne dos seus ofícios, mas sim convidar para uma reflexão sobre a importância da afetividade em todos os seus sentidos, dentro do ambiente escolar, como parte essencial do desenvolvimento completo de seus alunos. A dimensão afetiva vai ocupar um lugar central na construção do sujeito e de seu conhecimento, relacionando a psicogênese e sua história, o que

\footnotetext{
${ }^{6}$ Consideramos nesse item, a possibilidade do aluno aprender, quando o meio proporciona condições e experiências significativas para isso.

\section{POLÊM!CA $\mid$ LABORE}

Polêmica - Revista Eletrônica da Uerj - Rua São Francisco Xavier, 524, $1^{\circ}$ andar bloco D, sl.1001 • Tels.: +55 21 2334-4088 / 4087 • http://www.e-publicacoes.uerj.br/index.php/polemica/index http://www.labore.uerj.br • laboreuerj@yahoo.com.br
} 
nos remete à relação indissociável entre as interações humanas e a constituição do sujeito, e que o leva a propor o estudo do ser humano em sua totalidade.

Quanto ao impacto da formação continuada na aprendizagem dos professores, constatamos a "Disposição e capacidade de coordenar grupos e colaborar com os demais professores" e a "Aprendizagem de habilidades práticas referidas a como ensinar os conteúdos das disciplinas em que atua" com os maiores percentuais de pouca influência, correspondendo a $61,8 \%$ e $61,7 \%$, respectivamente. Esses dois aspectos recaem nos conhecimentos experienciais, defendido por Tardif (2002). Se já conhecemos o poder do conhecimento compartilhado, por que ele continua sendo ignorado pelos programas de formação continuada? Nóvoa (2001), em uma entrevista dada à revista Nova Escola, ponderou:

[...] novas práticas de ensino só nascem com a recusa do individualismo. Historicamente, os docentes desenvolveram identidades isoladas. Falta uma dimensão de grupo, que rejeite o corporativismo e afirme a existência de um coletivo profissional. Refiro-me à participação nos planos de regulação do trabalho escolar, de pesquisa, de avaliação conjunta e de formação continuada, para permitir a partilha de tarefas e de responsabilidades. As equipes de trabalho são fundamentais para estimular o debate e a reflexão. É preciso ainda participar de movimentos pedagógicos que reúnam profissionais de origens diversas em torno de um mesmo programa de renovação do ensino (NÓVOA, 2001, não paginado).

Ainda sobre o segundo item de menor impacto desse bloco, de número 33, que aborda a "aprendizagem de habilidades práticas referidas a como ensinar os conteúdos das disciplinas em que atua", recorreu-se a Shulman (1986 apud MIZUKAMI, 2004), que preocupou-se em discutir como o professor aprende a ensinar aquilo que ele já sabe, como tornar o conteúdo que já conhece, ensinável. O fato de o professor conhecer a história do Brasil, por exemplo, não significa que ele saiba como ensinar esse conteúdo aos seus alunos. Por isso, a importância de se trabalhar habilidades práticas com os professores em exercício, oferecendo subsídios para esse profissional promover uma aprendizagem significativa em seus alunos.

Temos consciência de que essa visão do que seja "conhecer o conteúdo que se deve ensinar" é inovadora para muitos professores e/ou futuros professores, pois são poucos os cursos de graduação em que encontramos disciplinas que discutam essas problemáticas e que façam uma estreita ligação entre o conteúdo específico e as reflexões históricas e filosóficas de sua produção (CARVALHO; PEREZ, 2001, p. 109-110).

Ao analisarmos o discurso direto de algumas participantes, entenderemos o porquê das formações não terem impactado na aprendizagem dos professores. Vejamos:

\section{POLÊM!CA $\mid$ LABORE}

Polêmica - Revista Eletrônica da Uerj - Rua São Francisco Xavier, 524, $1^{\circ}$ andar bloco D, sl.1001 • Tels.: +55 21 2334-4088 / 4087 • http://www.e-publicacoes.uerj.br/index.php/polemica/index http://www.labore.uerj.br • laboreuerj@yahoo.com.br 
Os momentos de módulos (formação) são mais direcionados para transmissão de recados e conversa sobre os problemas burocráticos (preenchimento do diário, data de entrega do planejamento, organização de eventos etc.) (P-55, 2019).

A formação continuada deixa muito a desejar. Precisamos de uma formação que realmente seja proveitosa e com assuntos que façam parte da nossa realidade para que possamos absorver e praticar o que aprendemos (P-59, 2019).

Acho que as formações deveriam ser realizadas com intuito de aprendizado para os professores. Porém as mesmas são realizadas para dar recados. (P-54, 2019).

Esses relatos remetem a um descaso preocupante dos sistemas de ensino para com todo marco teórico e as políticas públicas para a educação, especialmente para a formação de professores.

Se a formação continuada se configura em um dever e um direito do professor, é preciso que se assegure que essa formação seja ofertada com maior índice de qualidade possível e que esteja em coerência com a realidade daquela escola, pois só assim os conhecimentos adquiridos farão diferença na prática docente e na relação do professor com seus alunos.

\section{O impacto da formação continuada em sala de aula e na aprendizagem dos alunos}

A análise dos dados que tratam da formação continuada na aprendizagem dos professores, permitiu-nos inferir que os professores possuem altas demandas de necessidades de formação continuada, visto o pouco impacto dessa em suas aprendizagens.

Se partimos da concepção que a qualidade da educação oferecida em sala de aula está diretamente relacionada à formação do professor em exercício, então, é nesse contributo que os programas de formação precisam concentrar seus esforços, se pretendem melhorar o rendimento dos alunos.

A função do professor em sala de aula é de proporcionar a construção do conhecimento do aluno. Para tanto, esse professor necessita de um bom embasamento teórico dos conteúdos que leciona, de como o processo de construção do conhecimento se solidifica, assim como, conhecimento de didática e de metodologias, de como trabalhar na e com a diversidade, de forma que consiga abranger todas as necessidades individuais de sua turma. Nesse sentido, e em consonância com esta pesquisa, é coerente que o pouco impacto da formação na aprendizagem dos professores impacte negativamente na aprendizagem dos alunos, revelados nesse bloco.

\section{POLÊM!CA $\mid$ LABORE}

Polêmica - Revista Eletrônica da Uerj - Rua São Francisco Xavier, 524, $1^{\circ}$ andar bloco D, sl.1001 • Tels.: +55 21 2334-4088 / 4087 • http://www.e-publicacoes.uerj.br/index.php/polemica/index http://www.labore.uerj.br • laboreuerj@yahoo.com.br 
Os itens "Melhoria da atenção aos alunos de baixo rendimento, oferecendo alternativas para aprimorar o desempenho deles", com 69,5\% dos respondentes no segmento inferior, seguido do item "Melhoria da aprendizagem e do desempenho dos alunos", com 62,1\% de respostas também no segmento inferior e "Mudanças na concepção do ensino e da profissão docente", apresentando o percentual de $61 \%$ na primeira amplitude, despertam-nos para a precariedade dos cursos de formação continuada e a consequente ausência de mudanças nesses profissionais, refletindo, naturalmente, na qualidade da aprendizagem dos alunos.

Se a formação continuada não está contemplando os conteúdos necessários para a prática docente, tampouco irá impactar na aprendizagem do professor. Em coerência com essa realidade, os sujeitos do discurso revelam que a aprendizagem dos alunos também não está sendo afetada com essa formação. Se o objetivo final dessa formação é a qualidade da educação, e ele não está sendo cumprido, como nos mostra os resultados da pesquisa, o que justifica, então, os investimentos, principalmente financeiros, nesse campo do conhecimento?

Nenhum dos itens abordados nesse bloco, que faz saber: "Melhor utilização das metodologias de ensino, tais como a aprendizagem cooperativa, trabalho por projeto, aprendizagem baseada em problemas, o ensino para a compreensão, dentre outras; Melhoria do clima da sala de aula e das relações com os alunos"; "Maior envolvimento, interesse e motivação dos alunos"; "Melhoria da aprendizagem e do desempenho dos alunos"; "Melhoria da atenção aos alunos de baixo rendimento, oferecendo alternativas para aprimorar o desempenho deles" e; "Mudanças na concepção do ensino e da profissão docente, o impacto da formação continuada na sala de aula e na aprendizagem dos alunos" chegou aos $80 \%$ que é o limite entre o ruim e o aceitável. Se todos os itens estão abaixo do que consideramos aceitável, por que estamos oferecendo a formação?

Partimos do princípio que essa realidade precisa mudar e essa formação precisa ser oferecida com qualidade e consistência, capaz de despertar o sentido no professor, possibilitando assim, seu desenvolvimento pessoal e profissional.

\section{Considerações finais}

Partindo do pressuposto que nenhuma licenciatura é capaz de capacitar o graduando para todas as complexidades da sala de aula e nem para o enfrentamento dos inúmeros contextos existentes, compreende-se, então, a formação continuada como uma necessidade para os

\section{POLÊM!CA $\mid$ LABORE}

Polêmica - Revista Eletrônica da Uerj - Rua São Francisco Xavier, 524, $1^{\circ}$ andar bloco D, sl.1001 • Tels.: +55 21 2334-4088 / 4087 • http://www.e-publicacoes.uerj.br/index.php/polemica/index http://www.labore.uerj.br • laboreuerj@yahoo.com.br 
professores, se almejamos que o processo educativo caminhe e se desenvolva plenamente e com a qualidade que carece.

Consideramos a escola lócus privilegiado para a atividade profissional, que deve ter como prioridade incitar nos professores as necessidades de formação, desejos de aprofundamento dos saberes, motivos pessoais para seu desenvolvimento profissional, sentidos e significados, em consonância com o Projeto Político da Escola, no intuito de melhorar a qualidade da educação.

Se os conteúdos tratados na formação continuada e as atividades dessa formação, não impactam na aprendizagem do professor, tampouco, contemplará uma ressignificação da sua prática, não impactando em nada na aprendizagem de seu aluno. Se é verdade que não podemos admitir que a formação continuada em serviço seja perda de tempo e de dinheiro, que não contemple um grau alto de satisfação, por que a formação continuada ainda está tão aquém daquilo que as políticas públicas preveem e das necessidades de formação dos professores?

Finaliza-se propondo a reflexão sobre a necessidade de se repensar políticas que assegurem a oferta de cursos que vão de encontro às necessidades do professorado, condizentes com seus respectivos contextos e realidades. O poder público deve se responsabilizar pela oferta não somente de cursos, como também, oferecer condições que permitam a participação dos professores nos mais diferentes eventos, cursos personalizados que levem em conta os ciclos do desenvolvimento profissional, o nível de ensino que o professor atua, o contexto em que esse profissional trabalha e suas necessidades individuais, pois, só assim é possível garantir uma educação de qualidade para todos. Sugere-se, por fim, a busca pelos sistemas e instituições de ensino, por parcerias com a comunidade científica, visto a capacidade dessa para propor uma formação continuada consistente e que faça sentido para o sujeito em formação, que se preocupe com as necessidades individuais dos profissionais, em consonância com as necessidades sociais emergentes.

\section{Referências}

ALMEIDA, M. I. O Sindicato como instância formadora dos professores: novas contribuições ao desenvolvimento profissional. Tese (Doutorado em Educação) - Faculdade de Educação, Universidade de São Paulo, São Paulo, 1999.

ALMEIDA, M. I. Desenvolvimento profissional docente: uma atribuição que também é do sindicato. In: REUNIÃO ANUAL DA ANPED, 23., 2000, Caxambu. Anais.... Caxambu: ANPED, 2000.

\section{POLÊM!CA $\mid$ LABORE}

Polêmica - Revista Eletrônica da Uerj - Rua São Francisco Xavier, 524, $1^{\circ}$ andar bloco D, sl.1001 • Tels.: +55 21 2334-4088 / 4087 • http://www.e-publicacoes.uerj.br/index.php/polemica/index http://www.labore.uerj.br • laboreuerj@yahoo.com.br 
ANDRÉ, M. Pesquisa sobre Formação de Professores: tensões e perspectivas do Campo. In: FONTOURA, H.; SILVA, M. (Org.). Formação de Professores, Culturas - Desafios a Pós-Graduação em Educação em suas múltiplas dimensões. Rio de Janeiro: ANPED, 2011. V. 2, p. 24-36.

AQUINO, O. F.; GONZÁLEZ, A. M. Ensaio para uma mudança de paradigma na formação de professores. In: BERNARDES, Sueli Teresinha de Abreu. (Org.). Pesquisas sobre o professor e a educação básica. Curitiba: Editora CRV, 2018. p. 192-210.

BARRETO, E. S. S. Políticas de formação docente para a Educação Básica no Brasil: embates contemporâneos. Revista Brasileira de Educação, v. 20, n. 62, p. 679-701, jul./set. 2015.

BRAND, R. M. W. Um contexto em mudança: Trabalho, saúde e profissão docente. In: SIMPÓSIO NACIONAL DE EDUCAÇÃO, 2.; SEMANA DE PEDAGOGIA, 21., 2010, Cascavel. Anais... Cascavel: Ed. da UNIOESTE, 2010. p. 1-15.

BRASIL. Ministério da Educação. Conselho Nacional de Educação. Resolução No 2, de $1^{\text {o }}$ de julho de 2015. Define as Diretrizes Curriculares Nacionais para a formação inicial em nível superior e para a formação continuada. Diário Oficial da União, Brasília, 2 de jul. 2015a, Seção 1.

BRASIL. Ministério da Educação. Referenciais para formação de professores. 2. ed. Brasília, DF: Secretaria de Educação Fundamental, 2002.

BRASIL. Parecer CNE/CP No: 2/2015. Diretrizes Curriculares Nacionais para a formação inicial e continuada dos profissionais do magistério da educação básica. Diário Oficial da União, Brasília, 25 jun. 2015 b, Seção 1.

BRASIL. INEP - Instituto Nacional de Estudos e Pesquisas Educacionais Anísio Teixeira. Censo Escolar, 2017. Disponível em: http://portal.inep.gov.br/censo-escolar. Acesso em: 21 jul. 2019.

BRASIL. INEP - Instituto Nacional de Estudos e Pesquisas Educacionais Anísio Teixeira. Relatório do $2^{\circ}$ Ciclo de Monitoramento das Metas do Plano Nacional de Educação - 2018. Brasília, DF: Inep, 2018 a.

BRASIL. INEP - Instituto Nacional de Estudos e Pesquisas Educacionais Anísio Teixeira. Relatório do Índice de Desenvolvimento da Educação (IDEB). Dados do estado de Minas Gerais. 2018b. Disponível em: http://www.inep.gov.br. Acesso em: 15 jul. 2019.

BRASIL. Lei n ${ }^{\circ}$ 9.394, de 20 de dezembro de 1996. Estabelece as diretrizes e bases da educação nacional. Diário Oficial da União, Brasília, 23 dez. 1996.

BRASIL. Plano Nacional de Educação 2014-2024: Lei no 13.005 , de 25 de junho de 2014. Aprova o Plano Nacional de Educação (PNE) e dá outras providências (Metas e Estratégias). Biblioteca Digital da Câmara dos Deputados. Brasília : Câmara dos Deputados, Edições Câmara, 2014. (Série Legislação, n. 125).

CANDAU, V. M. F. Formação continuada de professores: Tendências atuais. Petrópolis, RJ: Vozes, 1998.

CARVALHO, A. M. P; PEREZ, D. G. O saber e o saber fazer dos professores. In: CASTRO, A. D. de; CARVALHO, A. M. P. de (Org.). Ensinar a Ensinar - Didática para a Escola Fundamental e Média. São Paulo: Pioneira, 2001. p. 107-121.

CUNHA, M. I. A docência como ação complexa. In: CUNHA, M. I. (Org.). Trajetórias e lugares de formação da docência universitária: da perspectiva individual ao espaço institucional. Araraquara, SP: Junqueira \& Marin; Brasília, DF: CAPES; CNPq, 2010.

CUNHA, M. I. O tema da formação de professores: trajetórias e tendências do campo na pesquisa e na ação. Educ. Pesq., São Paulo, n. 3, p. 609-625, jul./set. 2013.

\section{POLÊM!CA $\mid$ LABORE}

Polêmica - Revista Eletrônica da Uerj - Rua São Francisco Xavier, 524, $1^{\circ}$ andar bloco D, sl.1001 • Tels.: +55 21 2334-4088 / 4087 • http://www.e-publicacoes.uerj.br/index.php/polemica/index http://www.labore.uerj.br • laboreuerj@yahoo.com.br 
CUNHA, M. I. Formação de professores: espaços e processos em tensão. In: SILVA JÚNIOR, C. A.; GATTI, B. A.; MIZUKAMI, M. G. N.; PAGOTTO, M. D. S.; SPAZZIANI, M. L. (Org.) Por uma revolução no campo da formação de professores. São Paulo: Editora Unesp, 2015. p. 85-95.

DAVIS, C. L. F. et al. Formação continuada de professores em alguns estados e municípios do Brasil. Cadernos de Pesquisa, São Paulo, v. 41, n. 144, p. 826-849, set./dez. 2011. Disponível em: http://www.scielo.br/scielo.php?script=sci_abstract\&pid=S010015742011000300010\&lng=en\&nrm=iso\&tlng=pt. Acesso em: 26 jun. 2019.

DEBESSE, M. Um problema clave de la educación escolar contemporânea. In: DEBESSE, M.; MIALARETY, G. (Ed.). La formación de los enseñantes. Barcelona: Oikos- Tau, 1982.

DEJOURS, C. A loucura do trabalho: estudo de psicopatologia do trabalho. São Paulo: Cortez Editora, 1988.

DOURADO, L. F. Diretrizes Curriculares Nacionais para a formação inicial e continuada dos profissionais do magistério da educação básica: concepções e desafios. Educ. Soc., Campinas, v. 36, n. 131, p. 299-324, abr./jun. 2015. Disponível em: http://www.scielo.br/pdf/es/v36n131/1678-4626-es-36-131-00299.pdf. Acesso em: 4 set. 2019.

FERRY, G. El trayecto de la formación. Los enseñantes entre la teoría y la práctica. Barcelona: Paidós, 1991.

FIORENTINI, D. A pesquisa e as práticas de formação de professores de Matemática em face das políticas públicas no Brasil. Bolema, Rio Claro, v. 21, n. 29, p. 43-70, 2008.

FIORENTINI, D.; CRECCI, V. M. Práticas de desenvolvimento profissional sob a perspectiva dos professores. DiversaPrática, v. 1, n. 1, p. 65-76, jul./dez. 2012.

FIORENTINI, D.; CRECCI, V. Desenvolvimento profissional docente: Um termo guarda-chuva ou um novo sentido à formação? Formação Docente - Revista Brasileira de Pesquisa sobre Formação de Professores, Belo Horizonte, v. 5, n. 8, p. 11-23, jan./jun. 2013. Disponível em: https://revformacaodocente.com.br/index.php/rbpfp/article/view/74. Acesso em: 10 jul. 2019.

FREIRE, P. Pedagogia da Autonomia: saberes necessários à prática educativa. São Paulo: Paz e Terra, 1996.

FREITAS, R. A. M. M. Formação de conceitos na aprendizagem escolar e atividade de estudo como forma básica para a organização do ensino. EducAtiva, Goiânia, v. 19, n. 2, p. 388-418, maio/ago. 2016.

FREITAS, C. A. F; CASTRO, R. Saúde do professor: Um olhar para o Brasil e para os servidores da rede municipal de ensino de Uberaba-MG. In: CONGRESSO NACIONAL DE EDUCAÇÃO - EDUCERE, 12., 2015, Curitiba. Anais... Curitiba: PUCPR, 2015. p. 15880-15893.

FULLAN, M. The new meaning of educational change. Chicago: Teacher College Press, 1991.

GATTI, B. A.; BARRetTO, E. S. Professores do Brasil: impasses e desafios. Brasília: UNESCO, 2009.

GATTI, B. A. Formação de professores: compreender e revolucionar. In: SILVA JÚNIOR, C. A.; GATTI, B. A.; MIZUKAMI, M. G. N; PAGOTTO, M. D. S.; SPAZZIANI, M. L. (Org.). Por uma revolução no campo da formação de professores. São Paulo: Editora Unesp, 2015. p. 229-243.

GATTI, B. A. et. al. Professores do Brasil: novos cenários de formação. Brasília: Unesco, 2019.

GIL, A. C. Como encaminhar uma pesquisa? In: GIL, A. C. (Org.). Como elaborar projetos de pesquisa. 4. ed. São Paulo: Atlas, 2002.

GOMES, L.; BRITO, J. Desafios e possibilidades ao docente e à sua relação com a saúde. Estudos e pesquisas em Psicologia, Rio de Janeiro, ano 6, n. 1, 2006.

\section{POLÊM!CA $\mid$ LABORE}

Polêmica - Revista Eletrônica da Uerj - Rua São Francisco Xavier, 524, $1^{\circ}$ andar bloco D, sl.1001 • Tels.: +55 21 2334-4088 / 4087 • http://www.e-publicacoes.uerj.br/index.php/polemica/index http://www.labore.uerj.br • laboreuerj@yahoo.com.br 
HUBERMAN, M. O ciclo de vida profissional dos professores. In: NÓVOA, A. (Org.). Vidas de professores. Porto: Porto Editora, 1995. p. 31-61.

IMPACTO. In: Dicio, Dicionário Online de Português. Porto: 7Graus, 2019. Disponível em: https://www.dicio.com.br/impacto/. Acesso em: 15 nov. 2019.

LEONE, N. M. A inserção no exercício da docência: necessidades formativas de professores em seus anos iniciais. São Paulo: Cultura Acadêmica, 2012.

LIBÂNEO, J. C. Prática educativa, pedagogia e didática. In: LIBÂNEO, J. C. Didática. São Paulo: Cortez, 1994, p. 15-31.

MARCELO GARCÍA, C. Estrutura conceptual da formação de professores. In: MARCELO GARCÍA, C. Formação de professores: para uma mudança educativa. Lisboa: Porto Editora. 1999.

MARCELO GARCÍA, C. Las tecnologias para la innovación y la práctica docente. Revista Brasileira de Educação, Rio de Janeiro, v. 18, n. 52, jan./mar. 2013. DOI: http://dx.doi.org/10.1590/S1413 24782013000100003.

MARKONI, M. A; LAKATOS, E. M. Fundamentos de Metodologia Científica. 5. ed. São Paulo: Atlas, 2003. MEC - MINISTÉRIO DA EDUCAÇÃO. Conselho Nacional de Educação - CNE. Apresentação. MEC, Brasília, 2018.

MEDINA, A.; DOMÍNGUEZ, C. La formacíon del profesorado en una sociedad tecnológica. Madrid: Cincel, 1989.

MILLER, H. The state of the academic profession. England: The University of Aston in Birmingham, 1992.

MIZUKAMI, M. G. N. Aprendizagem da docência: algumas contribuições de L. S. Shulman. Revista do Centro de Educação, v. 29, n. 2, 2004. Disponível em: http://coralx.ufsm.br/revce/revce/2004/02/a3.htm. Acesso em: 20 mar. 2018

NÓVOA, A. Entrevista dada à Revista Nova Escola: "Professor se forma na escola". 01 de maio de 2001. Disponível em: https://novaescola.org.br/conteudo/179/entrevista-formacao-antonio-novoa. Acesso em: 20 jul. 2019.

NÓVOA, A. Formação de professores e formação docente. In: NÓVOA, A. Os professores e a sua formação. Lisboa: Publicações Dom Quixote, 1992.

OLIVEIRA, M. M. Como fazer pesquisa qualitativa. Petrópolis, RJ: Vozes, 2007.

PASSOS, C. et al. Desenvolvimento profissional do professor que ensina Matemática: uma meta-análise de estudos brasileiros. Quadrante, Revista teórica e de investigação, Lisboa, v. 15, n. 1-2, p. 93-219, 2006.

RAMALHO, B. L. Formar o professor, profissionalizar o ensino - perspectivas e desafios. Porto Alegre: Sulina, 2004.

RAMALHO, B. L; NUÑEZ, I. B. (Org.). Diagnóstico das necessidades formativas de professores do ensino médio no contexto das reformas curriculares. Educação em Questão, Natal, v. 40, n. 26, p. 69-96, jan. /jun. 2011.

RODRIGUES, M. A. P. Análise de práticas e de necessidades de formação. Lisboa, Portugal: Direcção-Geral de Inovação e Desenvolvimento Curricular, 2006. (Coleção Ciências da Educação, v. 50).

\section{POLÊM!CA $\mid$ LABORE}

Polêmica - Revista Eletrônica da Uerj - Rua São Francisco Xavier, 524, $1^{\circ}$ andar bloco D, sl.1001 • Tels.: +55 21 2334-4088 / 4087 • http://www.e-publicacoes.uerj.br/index.php/polemica/index http://www.labore.uerj.br・ laboreuerj@yahoo.com.br 
SILVA, M. O. E. A análise de necessidades de formação na formação contínua de professores: um caminho para a integração escolar. 2000. 286 f. Tese (Doutorado em Educação) - Faculdade de Educação, Universidade de São Paulo, São Paulo, 2000.

TABILLE, A. F.; JACOMETO, M. C. D. J. Fatores influenciadores no processo de aprendizagem: um estudo de caso. Rev. psicopedag., São Paulo, v. 34, n. 103, 2017.

TARDIF, M. Os professores diante do saber: esboço de uma problemática do saber docente. In: TARDIF, M. Saberes docentes e formação profissional. Petrópolis, RJ: Vozes, 2002. p. 31-55.

TODOS PELA EDUCAÇÃO. O que são e para que servem as Diretrizes Curriculares? Todos pela Educação, São Paulo, 8 jan. 2018. Disponível em: https://www.todospelaeducacao.org.br/conteudo/o-que-sao-e-para-queservem-as-diretrizes-curriculares-/. Acesso em: 20 jun. 2019.

VAILLANT, D; MARCELO GARCÍA, C. Ensinando a ensinar: as quatro etapas de uma aprendizagem. Curitiba: UTFPR, 2012.

VYGOTSKY, L. S. Lo Sviluppo psichico del bambino. Roma: Riuniti, 1973.

ZABALZA BERAZA, M. A. Los diarios de los profesores como documentos para estudiar cualitativamente los dilemas prácticos de los profesores. Santiago: Proyecto de Investigación de Acceso a Catedra, 1987.

ZEICHNER, K. M. Novos caminhos para o practicum: uma perspectiva para os anos 90. In: NÓVOA, A. Os professores e sua formação. Lisboa: Publicações Dom Quixote, 1992.

Recebido em: 26/03/2020.

Aceito em: 14/10/2021.

\section{POLÊM!CA $\mid$ LABORE}

Polêmica - Revista Eletrônica da Uerj - Rua São Francisco Xavier, 524, $1^{\circ}$ andar bloco D, sl.1001 • Tels.: +55 21 2334-4088 / 4087 • http://www.e-publicacoes.uerj.br/index.php/polemica/index http://www.labore.uerj.br • laboreuerj@yahoo.com.br 